\title{
$(\mathrm{cc}) \mathrm{BY}$
}

\section{Humanism in the Digital Age}

\author{
Massimo Lollini, Editor, Humanist Studies \& the Digital Age
}

Welcome to Humanist Studies \& the Digital Age, a new online open access journal devoted to the reformulation of received philological and philosophical ideas of writing and reading literary works, motivated by the advent of electronic texts. There has never been a time in which the human was not a work in progress (Sheehan). Humanism today must address not only the plurality of stages on the road towards the formation of ideas of humanity but also the unfinished nature of the human project. While this is not solely the result of a technological revolution, it has nonetheless become obvious that technology is playing a crucial role in the new perspectives opened to humanism. The process that has led to contemporary understanding of technology in relation to the question of humanity is very long and complex. Scholars suggest a division of the evolution of the support and transmission of knowledge into four main revolutionary changes: 1) from orality to writing; 2) from volumen to codex, including the beginning of the book form; 3) from early book form to printed books; 4) from late print forms to digital forms (Roncaglia x-xi). Writing, reading, and their different supports were and still are at the core of the human idea.

Resistance to change, denial, and sense of estrangement have accompanied the turning points in the development of the "technologizing of the word" in relation to human selfawareness and consciousness (Ong). It is still revealing to re-read in Plato's Phaedrus the critical comments of Socrates on the gift of writing from the Egyptian god Theuth to King Thamus:

[T] his discovery of yours will create forgetfulness in the learners' souls, because they will not use their memories; they will trust to the external written characters and not remember of themselves. The specific which you have discovered is an aid not to memory, but to reminiscence, and you give your disciples not truth, but only the semblance of truth; they will be hearers of many things and will have learned nothing; they will appear to be omniscient and will generally know nothing; they will be tiresome company, having the show of wisdom without the reality (emphasis added) (Phaedrus 274-75).

One can detect here the disquiet and disconcerted perception of the detachment from the notion of "truth" as living knowledge that took place in ancient Greece in the passage from the world of orality to the world of literacy. One can even argue that this perception alludes already to an idea of "virtual" reality and culture that is dismissed in the moment in which it is recognized because it goes against pre-alphabetic notions of literacy and culture. Nonetheless, the revolution introduced by alphabetic writing in Western culture could not stop because of these perturbed perceptions. Moreover, by writing the philosophy of Socrates, Plato contributed immensely to this radical cultural transformation. 
An equally radical change took place in the reading ethos of twelfth-century Europe, as the idea emerged that writing is not related only to Latin and lectio divina but can be used also to transcribe vernacular literature. While the use of paper in place of parchment accompanied the emergence of vernacular literatures, the technological revolution of alphabetic writing and reading was enhanced and reinforced by the logic and structural organization of the early book form. As Ivan Illich has shown, the sacred dimension of the divine lectio described by Hugh of Saint Victor's Didascalicon, a work written in the first half of the twelfth century, was lost along with the practice of monastic group and vocal reading. Hugh wrote his Didascalicon de studio legendi to praise with the monks the inspired richness and fruitfulness of this practice in the moment in which it was going to be substituted by a new technology of the book and scholastic reading as a predominantly silent activity performed by individuals. Hugh still considers reading a physical activity, one in which all the body and the senses are involved. Reading for him means to literally incorporate and embody the pages and the letters, triggering a fertility of sensory drives that would disappear in modern European languages (Hugh of Saint Victor III 1-12; Illich 54).

"Page" in Latin meant originally "vineyard"; hence the idea of reading as "harvesting grapes," a motor and sensory activity related to spiritual elevation (57). The illuminated manuscript is like a medieval cathedral with all its colors and decorations. These elements progressively disappear in the page of the new book format following the new indexing elements that create an abstract, bi-dimensional and disincarnate space for reading. The visible page ceases to be the record of speech and a series of commentaries freely available to the reader, to become a page laid out by an author responsible for choosing the subject and the ordinatio. Illich has rightly emphasized a distinct correspondence between the newly laid-out page and the new setting for reading-within the nascent universities that substitute monastic rituals with academic ones based on thought-through arguments. Even more significant for a discourse on humanism is the match between the emergence of selfhood understood as person and the emergence of the text from the pages of a book. In this transition the studium legendi ceases to be a way of living to become an activity increasingly devoted to the acquisition of knowledge (Illich 25, 65, 99).

Criticism of literacy and specifically of technological advancement as agent of change took place at the beginning of early modern Europe as well, when the printing revolution emerged. Dominican friar Fillippo di Strata expressed one of the most famous and vibrant instances of resistance to the technological advance represented by Gutenberg's movable type. Notoriously, he attempted to convince the Doge to ban the nascent printing industry from Venice, by stating that "Est virgo hec penna, meretrix est stampificata" ("The pen is a virgin; the printing press, a whore” Lowry 45). Filippo di Strata's complaint about the negative influence of print joins the voices of Socrates and Hugh of Saint Victor in pointing out a qualitative change in human knowledge and culture introduced by different technological advances. The technology of the word, be it expressed by writing or reading, in the form of codex or printed book, is seen as impoverishing human culture and experience of the world by neglecting the quality of human cultural endeavors in favor of quantitative, neutral, impersonal, and commercial criteria. 
Similar concerns have been expressed in regard to the fourth major revolution in the technology of the word, the one we are living today, the digital revolution. Jaron Lanier, former Internet enthusiast, has recently condemned Web 2.0, the digital design concept conceived as open culture, for degrading individual human values in favor of impersonality, anonymity, and crowd identity. Lanier laments the formation of a collectivist ethos through Google searches and Wikipedia uncontrolled use. This new reading ethos is accused of eliminating the importance and uniqueness of the individual voice and of filling the minds of the users with increasing amounts of uncontrolled sources and ultimately leading to mob rule. Lanier's actual criticism adds to those expressed more than a decade ago by Sven Birkerts's The Gutenberg Elegies, which postulated a decline in the quantity and quality of reading in our time due to the overwhelming advances of the Internet and other technologies of the "electronic culture."

Notwithstanding the harsh criticism, the early modern print revolution has continued to exert its pervasive influence in Western culture and society. Book technology still deeply conditions our actual ways of approaching culture, society, and the world. The emergence of a distinct humanist philology is principally linked to the inception of book technology in the thirteenth century. Since its origins, be they the Padua of Lovato Lovati (1240-1309) or earlier (Witt), humanism had its focal point in the awareness of the historical contingency of texts and human experience of time, to the point that even postmodern scholars who want to abandon rigidly conceived Enlightenment and Renaissance paradigms "are carrying forward, in a radical way, a project that began anew with the humanists: being skeptical about texts" (Witt 29). As for the emerging digital revolution and related "cognitive surplus" aided by new technologies (Shirky), one can only conclude that it will continue in the future in directions that are not completely predictable. Writing and reading are surely still at the core of the human enterprise, but in the new technological and social context they acquire unprecedented forms even when they recover usages of orality and sensory experiences. From this comes the deep need of thoroughly studying the new practices of textuality and their impact on the idea of humanism and the translation studi, the transferring our cultural legacy from earlier forms into digital technology.

Our own journal is contributing to this inquiry, devoting the first issue to the study of the evolution of Francis Petrarch's Rerum vulgarium fragmenta from manuscript culture to print and digital culture. The next issue will continue this study with essays and interventions that will present and discuss existing digital projects in the area of digital humanism and philology. On the one hand, we expect from the essays the delineation of new theoretical and practical perspectives; on the other hand, the interventions should present a "militant" character and comment on some specific elements of broader topics and projects. Moreover, Humanist Studies \& the Digital Age will include a section of "projects" that will showcase ongoing innovative research projects related to the construction and reception of hypertexts.

As Paul Eggert suggests, the digital revolution still needs to be philologically aware: "I am not certain that we are securely in 'post-philological days,' even though literary theorists tell their students this with great confidence. Indeed, I suspect that the ailing body has been 
needlessly medicalised and the death certificate prematurely signed" (82). The need for a renewed interest in philology in humanist studies comes from the emphasis that the digital revolution puts on fluid textuality. As John Bryant holds, "a fluid text is any literary work that exists in more than one version." The fluidity is due to the fact that "versions flow from one another." All works "are fluid texts" because of the nature of the writing and creative process. The material text is never fixed in one single form and "revision, publication, and reception urge us to recognize that the only 'definitive text' is a multiplicity of texts" (1-2). The notion of textual fluidity and variation is further enhanced considering the transformation that one text undergoes from manuscript to print culture and from print to digital culture. Moreover, the text's material presence changes with the reader and with translations and adaptations. Bryant follows Derrida's disregard of "nostalgia for origins" and of the idea of a truth free from "free-play." Bryant goes on to point out the need of new ways of reading, interpreting, and teaching, favoring a mode of interpretation that de-centers meaning and is happy with given and existing fragments of signification (10).

To what extent are we ready to immerse ourselves in the continuous creativity of the fluid text? Why should the free-play of the fluid text lead to a transcendence beyond "man and humanism," as Derrida and Bryant suggest? Is humanism buried once and for all by deconstructive philology? Is this a necessary and unavoidable process? To what extent are we ready to abandon the "culture creature comforts" produced by "definitive texts" and the ideology of authority, singularity, and authenticity (Bryant 10)? Bryant argues that even scholarly editions are subject to textual fluidity and that a critical authoritative edition of a particular text is never definitive. Is this enough to neglect the very notion of scholarly and critical editions? What kind of philology would be adequate to address the "fluid text"? George Landow has emphasized the convergence of critical theory with the practice of hypertextuality in the digital age. How are existing literary hypertext projects, constructed around major classics of world literature, addressing the issue of "authority"?

Hypertext theory and practice tend to blur the boundaries between reader and author. Landow speaks of hypertext readers as "wreaders" being at the same time writers and readers of the hypertext (Landow, Hyper/Text/Theory 14). Peter Shillingsburg has articulated this issue in the theory of "Write Acts" by which he means "the complex, never closed, serial event encompassing the creations, productions, and receptions at any and all places and times in which a written work is created, produced, and received" (81). In Shillingsburg's approach the emphasis is on the literary critic and philologist as responsible for envisioning the literary works in terms of "writing acts" more than on the user of a hypertext who is responsible for choosing different paths of reading available within the hypertext. Nonetheless, contemporary humanist philology should not stop posing the complex questions of readership of the digital projects. Is the emphasis on active reading as a special component of Web 2.0 justified by actual practices of reading hypertexts? How are these practices motivated and implemented?

The evolution of the support and transmission of knowledge has meant a continuous enlargement of audience from medieval court and city to modern nations. An international audience has always existed and in the past was favored by the presence of Latin as lingua 
franca for the intellectuals. However, the digital revolution is enhancing the international and global process of literary exchange in an unprecedented manner. The notion of world literature is controversial and problematic. The process of globalization has developed a double contradictory movement, one toward the global and the other toward a local idea of literature. The emergence of local philologies is mostly related to the defense and protection of minority languages and cultures within national environments. I need only mention here the Sardinian case in Italy (Maninchedda). These tensions suggest the possibility of a critical process of globalization, one that does not pursue the reductio ad unum but remains aware of local, regional, and national identities (Antonelli).

In what ways is digital textuality addressing the question of an increasingly global readership and audience? Will hypertextuality become an important, even privileged, form of world literature as a central and necessary reading and interpretative tool of literary phenomena involving broad geopolitical unities? In what ways and forms? What is the role of translation in the humanist philology associated with hypertextuality? These questions and the others introduced in the previous paragraphs will be at the center of the next issue of Humanist Studies \& the Digital Age. It is important to address these questions, to tackle with new perspectives the idea of European literature as "the story of the protracted attempts to synthesize rivalries and struggles into imagined unities" (Dainotto). Also, hypertext theory may help literary criticism to move away from the overwhelming feeling provoked by the idea of world literature as "the sum total of everything ever written" having "to deal not only with an endless array of texts but also with a plethora of local histories and competing literary cultures, which may not have anything resembling an overall history even if such a mass of material could be mastered and presented" (Darmosch 483).

Hypertext theory associated with the "paradigm of translation" brings to the center of the philological operation the question of the diversity of languages and calls for a continuous process of re-translation of the great works of world literature, one in which the reader is always involved. Is this the road map to the translation studi, the transferring of our cultural heritage into digital form that we are currently experiencing? One important starting point in the discussion ahead is the idea that the translation paradigm may favor a "hospitality of languages" much needed in our time, one in which the different languages nurture each other without collapsing into a neutral and aseptic meta-language driven by political and technological forces. This idea may be reinforced if it interacts with the hypertext paradigm and is mindful of the following formula for translation: "constructing comparables" aiming at a philological and historical synthesis ready to admit not only the non-existence of the perfect and total text but also the irreducible difference between the "peculiar" and the "foreign" within the "linguistic hospitality" opened by the "impassable status of the dialogicality of the act of translating" (Ricoeur 10). 


\section{Works Cited}

Antonelli, Roberto. "Spazio, tempo e testualità: l'ecdotica tra regioni e nazione." Maninchedda, Paolo. ed. Le prospettive delle filologie. Atti de seminario Alghero. 7 giugno 2003. Cagliari: Cuec/Centro di studi filologici sardi, 2004. 17-32. Print.

Bryant, John. The Fluid Text. A Theory of Revision and Editing for Book and Screen. Ann Arbor: The University of Michigan Press, 2002. Print.

Birkerts, Sven. The Gutenberg Elegies: The Fate of Reading in an Electronic Age. Winchester, MA: Faber and Faber, 1995. Print.

Dainotto, Roberto. "World Literature and European Literature." The Routledge Companion to World Literature. Eds. Theo D’haen, David Damrosch and Djelal Kadir. London; New York: Routledge, Forthcoming in 2011.

Darmosch, David. "Toward a History of World History” New Literary History, 39.3 (2008): 481-95. Print.

Derrida, Jacques. "Structure, Sign, and Play in the Discourse of the Human Sciences."

---. Writing and Difference. Trans. Alan Bass. London: Routledge, 2001. 278-94. Web. 3 Jan. 2011. < http://hydra.humanities.uci.edu/derrida/sign-play.html>.

Eggert, Paul. “These Post-Philological Days...” Ecdotica. 2 (2005): 80-98. Print.

Hugo de Sancto Victore [Hugh of Saint Victor]. Didascalicon de studio legendi. IntraText Digital Library, 2007. Web. 10 Jan 2011. <http://www.intratext.com/IXT/LAT0506/>.

Illich, Ivan. In the Vineyard of the Text, Chicago and London: Chicago UP, 1993. Print.

Lanier, Jaron. You Are Not a Gadget: A Manifesto. New York: Knopf, 2010. Print.

Landow, George. Hypertext 3.0: New Media and Critical Theory in an Era of Globalization. Baltimore: The Johns Hopkins University Press, 2006. Print.

---. Hypertext: The Convergence of Contemporary Critical Theory and Technology. Baltimore: The Johns Hopkins University Press, 1992. Print.

---. Ed. Hyper/Text/Theory. Baltimore: The Johns Hopkins University Press, 1994. Print.

Lowry, Martin. The World of Aldus Manutius: Business and Scholarship in Renaissance Venice. Oxford: Blackwell, 1979. Print.

Maninchedda, Paolo, ed. Le prospettive delle filologie. Atti de seminario Alghero 7 giugno 2003. Cagliari: Cuec/Centro di studi filologici sardi, 2004. Print.

Ong, Walter. Orality and Literacy: The Technologizing of the Word. New York: Routledge, 2002. Print.

Plato. Phaedrus, Trans. Benjamin Jowett. The Internet Classics Archive. Web. 4 Jan. 2011. $<$ http://classics.mit.edu/Plato/phaedrus.html $>$.

Ricoeur, Paul. On Translation. Trans. Eileen Brennan. London and New York: Routledge, 2006. Print. 
Roncaglia, Gino. La quarta rivoluzione. Sei lezioni sul futuro del libro. Bari: Laterza, 2010. Print.

Sheehan, Paul, ed. Becoming Human: New Perspectives on the Inhuman Condition. Westport, CT: Greenwood Publishing Group, 2003. Print.

Shillingsburg, Peter L. “Text as Matter, Concept, and Action.” Studies in Bibliography, 44 (1991). 31-82. Print.

Shirky, Clay. Cognitive Surplus Creativity and Generosity in a Connected Age. New York: The Penguin Press, 2010. Print.

Witt, Ronald G. "In the Footsteps of the Ancients": The Origins of Humanism from Lovato to Bruni. Boston: Brill, 2000. Print. 